\title{
Balance Sheet Asset Liquidity and Stock Returns: Future Cash Flow Volatility Signaling by Managers
}

\author{
Ben Angelo \\ Ball State University \\ bangelo@bsu.edu \\ Mitchell Johnston \\ University of Dayton \\ mjohnston2@udayton.edu
}

\begin{abstract}
We study the relationship between balance sheet asset liquidity and subsequent period returns. Our measure of balance sheet asset liquidity is negatively and significantly associated with subsequent period stock returns. More liquid firms earn significantly higher levels of returns over the subsequent period which is consistent with investor perceptions that liquidity is positively associated with risk. Relying on the existing literature related to balance sheet asset liquidity and precautionary savings, we find that firms with highly liquid balance sheets also realize significantly higher levels of cash flow volatility. This represents one possible explanation for why investors perceive more liquid firms as riskier than their less liquid counterparts.
\end{abstract}

JEL classification: G12

Keywords: Asset Liquidity, Balance Sheet Liquidity, Cash Flow Volatility, Precautionary Saving 


\section{Introduction}

Managers may increase cash holdings to improve overall liquidity in response to cash flow volatility (Bates, Kahle, \& Stulz, 2009; Han \& Qiu, 2007). In fact, we find that firms with highly liquid balance sheets realize higher levels of future cash flow volatility. Consistent with this finding, we also provide evidence that investors perceive more liquid firms as riskier than less liquid firms as measured by subsequent period returns, with highly liquid firms realizing higher returns over the subsequent period.

In this paper, we suggest a simple, holistic measure of balance sheet illiquidity. Unlike prior measures of liquidity, our measure focuses on the composition of the balance sheet as a whole. Prior measures focus primarily on cash and aggregate remaining asset line items to varying degrees. We anticipate that highly liquid firms will be associated with higher levels of future cash flow volatility, contributing to higher returns. We construct portfolios based on our measure of illiquidity and find that highly liquid firms earn significantly higher returns relative to less liquid firms. A spread portfolio formed based on our measure of illiquidity earns a value-weighted monthly raw return of $-0.57 \%$ with a $\mathrm{t}$-stat of -3.33 . The relationship between illiquidity and subsequent period returns is robust to controlling for common risk-factors and common determinants of returns. Our results are qualitatively consistent with several existing measures; however, to our knowledge, our measure is the only one that presents an economically meaningful and statistically significant return differential to the spread portfolio. We attribute this additional explanatory power to the fact that our measure assesses balance sheet liquidity on a line item basis 
while previous measures aggregate data. We argue that this makes our measure a more complete reflection of the true balance sheet liquidity of the firm.

It is, perhaps, counterintuitive that less liquid firms are considered less risky. However, both Bates et al. (2009) and Han and Qiu (2007) document a relationship between balance sheet asset liquidity and cash flow volatility. Relying on the intuition that balance sheet asset liquidity may be indicative of future cash flow volatility, we provide evidence that liquid firms experience higher levels of future cash flow volatility. This is consistent with the notion that firms may adjust liquidity in anticipation of future cash flow volatility. Our results suggest that more liquid firms, on average, experience higher levels of future cash flow volatility. We do not interpret this relationship as causal. Our results provide some intuition as to why investors may consider a more liquid firm riskier than a more illiquid counterpart. Across a variety of alternative measures of balance sheet asset liquidity, our measure is consistently the strongest predictor of future cash flow volatility.

Our paper extends the literature on balance sheet asset liquidity in two ways. First, we create a simple, holistic measure of illiquidity based on a complete set of asset line items. Second, we provide evidence that investors respond to the liquidity of the balance sheet which is not explained by commonly used risk-factors or a variety of other common return determinants. We are unaware of other measures of asset liquidity which present similar results. We also find that balance sheet illiquidity may indicate future cash flow volatility, which may explain the return relationship documented by our portfolio results. The majority of existing literature related to balance sheet illiquidity, precautionary savings, and cash flow volatility largely focuses on historic cash flow volatility (Bates et al., 2009; Han \& Qiu, 2007). To our knowledge, this is the first paper to document a similar relationship for future cash flow volatility. 
The remainder of the paper is as follows: in Section 2 we discuss prior literature on the liquidity of the balance sheet; in Section 3 we discuss our measure of illiquidity and provide summary statistics; in Section 4 we provide evidence of an association between illiquidity and stock returns; in Section 5 we provide evidence of an association between illiquidity and future cash flow volatility; in Section 6 we perform several robustness tests; and we conclude in Section 7.

\section{Balance Sheet Liquidity Background}

The balance sheet is one of the primary resources for investors to learn about a firm's financial condition and the actions of management (Cooper, Gulen, \& Schill, 2008; Hirshleifer, Kewei, Teoh, \& Yinglei, 2004; Sloan, 1996). One important dimension of the balance sheet is the liquidity of the assets (Bates et al., 2009; Gopalan, Kadan, \& Pevzner, 2012; Ortiz-Molina \& Phillips, 2014). Prior research has proposed varying methods for characterizing the liquidity of a firm's assets (Bates et al., 2009; Gopalan et al., 2012). These measures are then used to better understand the motivations of management in constituting the liquidity of their balance sheets. Bates, Kahle and Stulz (2009) use the cash ratio as a measure of firm liquidity and find that firms hold cash as a precaution against cash flow volatility. Gopalan, Kadan, and Pevzner (2012) use a variety of measures designed to capture balance sheet liquidity and note that balance sheet asset liquidity may influence the firm's stock liquidity. Using the measures proposed by Gopalan et al. (2012), Ortiz-Molina and Phillips (2014) show that firms with less liquid assets have higher costs

of capital. These prior findings underscore the importance of the liquidity of the balance sheet, which has implications for both asset pricing and corporate research. However, these proposed measures do not fully reflect the composition of the balance sheet. Bates et al. (2009) only consider 
cash in characterizing the liquidity of a balance sheet. Gopalan et al. (2012), consider the balance sheet in total, however, they aggregate line items such as property, plant and equipment with goodwill. Differing line items are unlikely to have the same level of liquidity.

The structure of the balance sheet is ordered in such a way that more liquid assets are placed higher on the balance sheet, and investors are likely to treat items presented lower on the balance sheet as distinct and less liquid than items higher on the balance sheet. Given the documented importance of balance sheet asset liquidity, it would be reasonable to consider the possibility that a more holistic analysis of the balance sheet may represent an improvement to existing measures of balance sheet illiquidity.

Even with just a portion of the balance sheet, prior research demonstrates that a variety of interesting intuitions can be obtained by considering the liquidity of the assets on the balance sheet. Bates et al. (2009) document that firms hold cash as a precaution against cash flow volatility. This result is consistent with findings by other researchers (Acharya, Almeida, \& Campello, 2007; Almeida, Campello, \& Weisbach, 2004; Han \& Qiu, 2007). In particular, Bates et al. (2009) find that firms operating in an industry with high cash flow volatility hold higher cash balances. However, only historic cash flow volatility is considered. It would seem likely that managers would adjust their balance sheets according to their beliefs about future cash flow volatility. In this way, the balance sheet will come to reflect management's belief about future cash flow volatility. Accordingly, we believe that a firm with more liquid assets will likely experience more future cash flow volatility and likely be considered as riskier relative to other firms in the same industry.

Multiple papers have documented return predictability based on information derived from the balance sheet (Cooper et al., 2008; Hirshleifer et al., 2004; Sloan, 1996), however, we are unaware of any papers that document a similar return predictability based on the liquidity of the 
balance sheet. Given the previously documented relationship between cash flow volatility and liquidity documented by Bates et al. (2009), we anticipate that investors will respond to the liquidity of the balance sheet. Firms with more liquid balance sheets may be signaling their belief about future cash flow volatility. Investors, in turn, may consider a more liquid asset composition riskier than a more illiquid asset composition.

To provide evidence of a relationship between balance sheet liquidity and future cash flow volatility, we develop a simple, holistic measure of a firm's balance sheet illiquidity and test the relationship between the level of liquidity and subsequent cash flow volatility. Consistent with our expectations, we find that firms with more liquid balance sheets are perceived as riskier as measured by subsequent period returns. In addition, we find that balance sheet illiquidity is negatively and significantly related to future cash flow volatility. Stated differently, a firm with a more liquid balance sheet will have higher future cash flow volatility. We detail our justification and construction of a balance sheet illiquidity measure in the following section.

\section{Balance Sheet Structure and Illiquidity}

We construct a simple, comprehensive metric designed to holistically measure a firm's balance sheet illiquidity. We base our measure on the requirement that a firm list assets on its balance sheet in decreasing order of liquidity (17 CFR 210.5-02). The most liquid item, cash, is at the top of the balance sheet while less liquid items, such as intangible assets, are near the bottom. Firms must report assets as separate line items on the balance sheet if the financial statements would otherwise be misleading to investors (17 CFR 210.4-01-a). Compustat aggregates balance sheet information in a similar structure by reporting nine separate asset line items in decreasing 
order of liquidity ${ }^{1}$. While Compustat further subdivides these items, we do not include the subdivisions in our analysis to ensure comparability between firms and to maximize sample size. We provide a detailed breakout of balance sheet items in the order of their liquidity for each asset line item on Panel B of Table 1.

Panel B of Table 1 reports the percentage of total assets for each of the asset line items from 1980 to 2018 by decade. The nine asset line items capture approximately $99.58 \%$ of total assets in Compustat, on average. Consistent with prior research, cash holdings are increasing across time (Bates et al., 2009; Foley, Hartzell, Titman, \& Twite, 2007). For the years 1981-1990, cash and short-term investments represent approximately $9.81 \%$ of total assets, on average. Cash and short-term investments increase to $17.73 \%$ on average during the period from 2010 to 2018 , a $7.92 \%$ increase. However, over the same time period, average total current assets decrease by $5.66 \%$, from $51.23 \%$ to $45.57 \%$ for the $1981-1990$ and $2010-2018$ time periods, respectively. The decline in the current assets is offset by an increase in less liquid assets, particularly, intangible assets. Intangible assets represent $2.48 \%$ of total assets, on average, from 1981 to 1990. Intangible assets increase to $20.47 \%$ of total assets for the $2010-2018$ time period, an approximate $17.99 \%$ increase. While cash balances are increasing, this increase is more than offset by the declines in the other current assets and the increase in intangible assets. This result contrasts with other researchers who conclude that firms are becoming more liquid as cash balances increase. We argue that it is unclear if an increase in cash directly leads to an increase in liquidity or if an increase in cash counterbalances increases in other less liquid balance sheet items. Figure 1 reports our measure of balance sheet illiquidity and the cash ratio over time. From this graph, we observe that

\footnotetext{
${ }^{1}$ cash and cash equivalents (CHE), receivables (RECT), inventory (INVT), other current assets (ACO), other investments (IVAO), investments in equity (IVAEQ), property, plant, and equipment (PPENT), intangibles and goodwill (INTAN), and other assets (AO)
} 
firms are holding more cash over time. However, our measure of illiquidity is remarkably consistent over the sample period.

\section{a. Data and Full Balance Sheet Liquidity}

To construct our measure of balance sheet illiquidity, we rely on annual financial data from the Compustat database from 1980 to 2018. We limit the sample to firms with at least 5 years of financial data available. We exclude financial firms with SIC codes 6000-6999 and utilities firms with SIC codes 4000-4999, as well as firms with zero or negative total assets. We also drop firms if the total assets reported by Compustat minus the sum of the nine asset line items reported by Compustat is greater than 1\%. Dropping these firms ensures that assets reported on the balance sheet have been assigned to a subcategory and prevents us from having to extrapolate missing asset data. Returns are from CRSP. We include common stock traded on the NYSE, NASDAQ, and AMEX stock exchanges. For portfolio formation, we exclude stocks with prices under 5 dollars and microcap stocks. We define microcap stocks as stocks with a market capitalization below the NYSE $20^{\text {th }}$ percentile. These restrictions ensure that our findings are not disproportionately affected by low priced or microcap securities and that our sample is comparable to prior research (Bates et al., 2009).

To capture the liquidity of a firm's balance sheet, we weight each asset line item based on the relative position of the line item within the balance sheet. The first item, cash and short-term investments, receives a weight of 1 . The second item, receivables, receives a weight of 2 , and so on. We multiply each weight by the respective asset line item. The sum of weighted asset line items is scaled by 45 multiplied by lagged total assets, where 45 is the sum of weights 1 through 9. As previously discussed, this measure relies on the fact that firms present asset line items on the balance sheet in order of liquidity. 
In total, the illiquidity measure for firm $i$ in year $t$ is calculated as follows:

$$
\text { Illiq }_{i, t}=\frac{\begin{array}{c}
1 \times C H E_{i, t}+2 \times R E C T_{i, t}+3 \times I N V T_{i, t}+4 \times A C O_{i, t}+5 \times P P E N T_{i, t} \\
+6 \times I V A E Q_{i, t}+7 \times I V A O_{i, t}+8 \times I N T A N_{i, t}+9 \times A O_{i, t}
\end{array}}{45 \times A T_{i, t-1}}
$$

We also construct alternative measures of firm liquidity as suggested by Gopalan et al. (2012) (GKP) as follows:

$$
\begin{gathered}
W A L 1_{i, t}=\frac{C H E_{i, t}}{A T_{i, t-1}} \times 1+\frac{\left(A T_{i, t}-C H E_{i, t}\right)}{A T_{i, t-1}} \times 0 \\
W A L 2_{i, t}=\frac{C H E_{i, t}}{A T_{i, t-1}} \times 1+\frac{\left(A C T_{i, t}-C H E_{i, t}\right)}{A T_{i, t-1}} \times 0.5 \\
W A L 3_{i, t}=\frac{C H E_{i, t}}{A T_{i, t-1}} \times 1+\frac{\left(A C T_{i, t}-C H E_{i, t}\right)}{A T_{i, t-1}} \times 0.75+\frac{\left(A T_{i, t}-A C T_{i, t}-I N T A N_{i, t}\right)}{A T_{i, t-1}} \times 0.5
\end{gathered}
$$

While both our measure and the measures used in Gopalan et al. (2012) rely on balance sheet structure to assess liquidity, our measure differs in two key ways. First, we weight each asset line item separately while GKP aggregates non-cash line items. This ensures that our measure is conceptually consistent with the SEC requirement that different categories of assets be reported as separate line items. By definition, separate asset line items will have different levels of liquidity. For example, receivables are more liquid than inventory and property. Disaggregating our weighting scheme allows us to focus on balance sheet liquidity as a whole rather than focusing primarily on cash. Second, we drop observations if the sum of balance sheet line items reported does not equal at least $99 \%$ of total assets reported. Prior measures interpolate values for missing balance sheet items. However, this interpolation may not accurately reflect the true liquidity of the 
balance sheet. Ensuring that the individual line items account for over $99 \%$ of total assets reported by Compustat helps to ensure that the balance sheet liquidity metric is an accurate reflection of the actual composition of the balance sheet.

\section{Balance Sheet Illiquidity and Stock Returns}

The information reported in the balance sheet can influence stock returns (Campbell, Hilscher, \& Szilagyi, 2008; Hirshleifer et al., 2004; Sloan, 1996; Titman, Wei, \& Xie, 2004). The balance sheet discloses the overall liquidity of the company. To provide preliminary evidence of the association between the liquidity of the balance sheet and returns, we create decile portfolios based on our measure of illiquidity. Portfolios are formed at the end of June of year $t$ based on the balance sheet illiquidity from year $t-1$. These portfolios are held for one year from the beginning of July of year $t$ until the end of June of year $t+1$, at which point the portfolio is rebalanced. Decile 1 is comprised of firms with the most liquid balance sheets, while decile 10 is comprised of the firms with the most illiquid balance sheets.

\section{a. Cross-Sectional Monthly Portfolio Returns Based on Liquidity}

In Table 2, we present equal and value weighted monthly raw returns for each decile portfolio over the 12 months following portfolio formation. We present the time series average of the portfolio raw returns from 1980 to 2018 . Additionally, we present portfolio returns for subgroups based on size terciles and we present portfolio returns for two sub-periods, 1980-1999 and 2000-2018. For each set of portfolios, we present a spread portfolio formed by buying decile 10 and shorting decile 1, as well as a t-stat associated with the spread portfolio. The null hypothesis is that the returns for the spread portfolio should be indistinguishable from zero. Any statistically 
significant deviation from zero provides evidence of an association between market returns and balance sheet illiquidity.

The relationship between returns and balance sheet liquidity is consistent with our expectations. Highly illiquid firms earn lower returns relative to the more liquid firms in the sample for both equal-weighted raw returns and value-weighted raw returns, as reported in Panel A. The spread between the highest decile portfolio and the lowest decile portfolio is $-0.46 \%$ on an equalweighted basis and $-0.57 \%$ on a value-weighted basis. In addition to being economically significant, these spreads are statistically significant. The equal-weighted spread portfolio has a tstat of -3.66 and the value-weighted spread portfolio has a t-stat of -3.33 . This result is consistent with more liquid firms being riskier than their illiquid counterparts.

In Table 3, we report five-factor risk-adjusted alphas from decile portfolios based on Fama and French (2015). We present the time series average of the Fama-French alphas from 1980 to 2018. Additionally, we present alphas for sub-groups based on size terciles and based on two subperiods, 1980-1999 and 2000-2018. We also present the alpha associated with the spread portfolio formed by buying decile 10 and shorting decile 1, as well as a t-stat associated with the spread portfolio. We rely on the five-factor model as the size, value, investment, and profitability factors are intended to proxy for risk factors. Controlling for these factors helps ensure that our result is distinct from existing risk measures already identified. For these tests, the null hypothesis is that the returns for the spread portfolio should be indistinguishable from zero. Any statistically significant deviation from zero provides evidence of an association between risk-adjusted returns and balance sheet illiquidity.

Across all firms, the equal-weighted five-factor alpha for the spread portfolio is $-0.58 \%$ and the associated t-stat is -4.97 . Similarly, the value-weighted five-factor alpha for the spread 
portfolio is $-0.67 \%$ with a t-stat of -3.62 . Highly liquid firms (decile 1 ) earn a value-weighted riskadjusted alpha of $0.42 \%$, while highly illiquid firms (decile 10) earn a value-weighted risk-adjusted alpha of $-0.25 \%$. The five-factor alphas associated with the equal-weighted portfolios are qualitatively similar. The return differential between firms with high balance sheet illiquidity and high balance sheet liquidity does not appear to be explained by the risk factors accounted for by the Fama-French five-factor model. Overall, these results are consistent with the raw return results reported in Table 2 and suggest an association between returns and balance sheet liquidity. Our inferences remain unchanged when using the Sharpe-Lintner CAPM model (Lintner, 1965; Sharpe, 1964) or the Fama-French three-factor model (Fama \& French, 1993).

The relationship between balance sheet liquidity and subsequent stock returns persists for both the 1980-1999 and 2000-2018 sub-periods as well as for all three size terciles. We present the raw return results for the sub-periods in Panel B of Table 2 and we present the five-factor alphas for sub-periods in Panel B of Table 3. On a value-weighted basis, the return for the spread portfolio from 1980 to1999 is $-0.37 \%$ with a t-stat of -1.78 . The value-weighted alpha is $-0.63 \%$ with a t-stat of -2.85 . From 2000 to 2018 , the economic magnitude of both the raw return and alpha decrease. The spread portfolio raw return for the $2000-2018$ sub-period is $-0.79 \%$ while the fivefactor alpha declines to $-0.70 \%$, with t-stats of -2.83 and -2.54 , respectively. We also consider the return results after controlling for firm size. Interestingly, the average monthly return differential is larger in absolute magnitude for larger firms. The average value-weighted monthly return spread for small firms is $-0.35 \%$, with a t-stat of -1.78 . For medium firms, the average value-weighted monthly return spread is $-0.52 \%$, with a t-stat of -2.97 . For large firms, the average value-weighted monthly return spread is $-0.57 \%$, with a t-stat of -3.20 . Across size sub-groups, firms with more liquid balance sheets earn higher returns, which is consistent with more liquid balance sheets being 
riskier. Alphas, for size terciles, present similar return patterns. The alpha for small firms is $-0.54 \%$ with a t-stat of -2.60 . Medium sized firms have an alpha of $-0.76 \%$ with a t-stat of -4.55 . Large firms have an alpha of $-0.72 \%$ with a t-stat of -3.71 . Neither controlling for size nor any of the five-factors associated with the Fama-French five-factor model appear to fully explain the return differentials between high balance sheet illiquidity firms and low balance sheet illiquidity firms.

We have conducted a variety of unreported robustness tests to verify that the return patterns are not simply an artifact of the model we selected for risk adjusting. We first supplement the fivefactor model with the Carhart (1997) momentum factor. The average alpha of the spread portfolio after incorporating the momentum factor is $-0.70 \%$ with a t-stat of -3.69 . Across the size subgroups and sub-periods, the alpha remains negative and significant. GKP find that stock liquidity and asset liquidity are related. Accordingly, we also supplement the five-factor model with the liquidity factor of Pástor and Stambaugh (2003). After adding the liquidity factor, the average alpha of the spread portfolio is -0.67 with a t-stat of -3.62 . Alphas for size sub-groups and subperiods all remain negative and significant after adding the liquidity factor. Overall, firms with highly illiquid balance sheets earn lower returns than firms with highly liquid balance sheets. The return predictability associated with balance sheet illiquidity is robust to a variety of factor models.

The return premium for firms with more liquid balance sheets appears consistent over the sample period. Figure 2 plots the annual value-weighted returns over the sample period for decile 1, decile 10, and the spread portfolio. Returns for decile 1 firms, which have the highest levels of liquidity, exceed returns for decile 10 firms, which are highly illiquid, for more than $76 \%$ of observations. The findings presented in Figure 2 are consistent with the portfolio results presented on Panel B of Tables 2 and 3. 
Overall, our results suggest that balance sheet illiquidity is predictive of the direction of future returns. This conclusion is consistent with prior research which shows that balance sheets are informative about future returns (Cooper et al., 2008; Hirshleifer et al., 2004; Sloan, 1996; Titman et al., 2004).

\section{b. Balance Sheet Illiquidity and Other Common Return Determinants}

To provide further evidence on the relationship between balance sheet liquidity and returns, we perform cross-sectional Fama-MacBeth regressions of monthly returns on balance sheet illiquidity and other common return determinants. We include controls for the cash ratio (Bates et al., 2009), weighted asset liquidity (Gopalan et al., 2012), return on assets, market-to-book, size, capital expenditures, and security illiquidity (Amihud, 2002). All monthly control variables are defined at the start of July of each year. As with portfolio sorts, we include observations from all firms traded on the NYSE, AMEX, and NASDAQ stock exchanges. We exclude observations with a stock price less than 5 dollars and microcap securities. Microcap securities are defined as securities below the $20^{\text {th }}$ size percentile of the NYSE. Following the suggestion of Greene (2012), all standard errors have been Newey-West adjusted for 5 lags.

We report the results for the Fama-MacBeth regressions in Table 4. Balance sheet illiquidity's coefficient across all considered sets of control variables is negative and significant. This is consistent with our portfolio findings where more illiquid firms realize lower returns over the subsequent year. To distinguish our measure of balance sheet illiquidity from other balance sheet liquidity metrics, columns 1 through 4 reflect Fama-MacBeth regressions including asset liquidity measures suggested by other researchers designed to capture a firm's balance sheet liquidity. Column 1 includes the cash ratio of Bates et al. (2009). Columns 2, 3, and 4 include the weighted asset liquidity measure suggested by Gopalan et al. (2012) as detailed in equation (2), 
equation (3), and equation (4), respectively. In column 1, the coefficient for our measure of balance sheet illiquidity is -0.0210 with an associated t-stat of -3.40 . In Column 2, the coefficient declines to -0.0199 with a t-stat of -3.08 . The coefficient is lowest in terms of magnitude and significance in column 3, with a coefficient of -0.0135 and a t-stat of -1.66 . The decline in significance and magnitude is not unexpected given the similarity between our measure and that of Gopalan et al. (2012)'s weighted asset liquidity measure. However, our measure is consistently negative and significant while the measures proposed by Gopalan et al. (2012) are never statistically significant. One of the primary distinctions of our balance sheet illiquidity measure is that it attempts to characterize balance sheet liquidity on a line item basis. The other measures aggregate line items or omit them from consideration in constructing their balance sheet illiquidity measure. The results in Panel A provide strong evidence that a complete consideration of the balance sheet represents an improvement to existing measures of balance sheet liquidity.

As with our portfolio findings, we consider regression results across sub-periods and size groups. The results of these Fama-MacBeth regressions are presented on Panel B of Table 4. Across both sub-periods, the relationship between balance sheet illiquidity and returns is negative and significant. From 1980 to 1999 , the coefficient is -0.0272 with an associated t-stat of -2.99 . In the later period, 2000-2018, the magnitude of the coefficient declines to -0.0144 and a t-stat of 1.76. Even across the shorter time periods, the coefficient on balance sheet illiquidity remains highly significant. Columns 3, 4, and 5 of Panel B represent the regressions of balance sheet illiquidity on monthly returns for small, medium, and large firms, respectively. The coefficients for small and medium firms are -0.0208 and -0.0297 with t-stats of -1.77 and -3.17 , respectively. For large firms, the coefficient on balance sheet illiquidity is -0.0108 , but with a statistically insignificant $\mathrm{t}$-stat of -1.20 . 
Across both our portfolio and Fama-MacBeth testing, the relationship between balance sheet illiquidity and subsequent period returns is consistently negative. This relationship is present even after we control for a variety of previously identified predictors of subsequent period returns as well as alternative measures of asset liquidity. Based on these results, using the full balance sheet to characterize the illiquidity of a firm's assets appears to be a substantive improvement over the cash ratio or balance sheet liquidity metrics from GKP. Portfolio returns are consistently negative and significant on a raw and risk-adjusted basis across sub-periods and size sub-groups. Negative coefficients are also present in our Fama-MacBeth regressions with a negative and significant coefficient for all but the subset of large firms. As the provenance of this return predictability is unclear, we have dedicated the following section into an investigation of why investors may consider less liquid firms to be less risky.

\section{Balance Sheet Illiquidity and Future Cash Flow Volatility}

Management may have differing motives for shifting the liquidity of the balance sheet. Bates et al. (2009) note four distinct possible motives for a firm's shifting towards more liquid balance sheets. In particular, they find that the precautionary motive is a critical determinant of management's decisions regarding the liquidity of the balance sheet. Bates et al. (2009) note that as historic industry cash flow volatility increases, firms also increase the liquidity of their balance sheets. Increasing the liquidity of the balance sheet acts as a precautionary step to mitigate exposure to cash flow volatility. However, management will likely consider both historic and anticipated future cash volatility when adjusting liquidity. Therefore, management may adjust their balance sheet liquidity based on their expectations for future cash flow volatility. By issuing financial statements, management reveals their balance sheet liquidity, which is potentially 
informative to investors regarding management's beliefs about expected future cash flow volatility. Based on this intuition, we consider the relationship between balance sheet illiquidity and future cash flow volatility realized by the firm. If more liquid firms face greater future cash flow volatility, investors may be able to anticipate and price this risk. Conversely, managers of illiquid firms expect lower levels of cash flow volatility in the future which may be associated with lower levels of risk.

In Table 5, we report results from regressions of future cash flow volatility on balance sheet illiquidity. We follow Bates et al. (2009) in estimating cash flow volatility at a firm level. We define forward cash flow volatility as the standard deviation of cash flow over the years $t+1$ to $t+10$. We define cash flow as earnings before interest and tax plus depreciation less interest expense and common dividends. We require a firm to have at least three years of observations to be included in our forward cash flow volatility calculation. Our control variables include capital expenditures, cash balance, the change in the cash ratio from the prior year, the market-to-book ratio, the natural $\log$ of total assets, research and development expenditures scaled by sales, industry cash flow volatility, net working capital, leverage, and lagged cash flow ${ }^{2}$. We scale all control variables by total assets unless otherwise noted. We winsorize all variables at the $1^{\text {st }}$ and $99^{\text {th }}$ percentiles. We cluster standard errors at the industry level.

We first establish the base relationship between illiquidity and future cash flow volatility. Column 1 reflects the regression of future cash flow volatility on our measure of balance sheet illiquidity. The negative coefficient is highly significant. We interpret this coefficient as evidence

\footnotetext{
${ }^{2}$ For the purposes of these regressions, we define cash flow following Bates et al. (2009) as earnings before interest and tax plus depreciation less interest expense and common dividends. However, we have also controlled for operating cash flow (OANCF) scaled by total assets, and our results are qualitatively similar. The use of operating cash flow truncates our sample period because operating cash flow was first required in 1988 with the introduction of the Statement of Cash Flows.
} 
that a highly illiquid balance sheet is associated with lower levels of future cash flow volatility. We do not interpret this relationship as a causal relationship between balance sheet illiquidity and future cash flow volatility, but interpret this as a channel by which investors may infer management's beliefs about future cash flow volatility. We have only included year fixed effects in this regression and cluster standard errors at the industry level. Our results are qualitatively similar without clustering or with clustering at a firm level.

Column 2 includes controls for balance sheet size, market-to-book, and historic industry cash flow volatility. We follow Bates et al. (2009) for the estimation of industry cash flow volatility, where industry is defined as the two-digit SIC industry. Given the prior identified relationship between balance sheet liquidity and industry cash flow volatility, we include industry level cash flow volatility in all regressions. Our result is robust to the use of historic industry cash flow volatility or firm specific cash flow volatility.

Column 3 includes a full set of control variables. Across all three sets of results, the relationship between balance sheet illiquidity and future cash flow volatility is negative and significant. The negative coefficient is consistent with less liquid firms having lower levels of future cash flow volatility, and could represent a possible explanation for the return premium realized by more liquid firms.

Column 4 includes a control for the weighted asset liquidity as suggested by GKP. As with our results associated with security returns, it is important to highlight the fact that our measure of balance sheet illiquidity is distinct from existing measures. This result provides evidence that using the full balance sheet illiquidity has incremental information beyond both the cash ratio as well as the GKP measure. Weighted asset liquidity of GKP does have a statistically significant relationship with future cash flow volatility. The sign is positive because GKP measures liquidity while we 
measure illiquidity. The intuition for both measures is the same. Higher levels of illiquidity are associated with higher subsequent cash flow volatility. While the GKP measure is significant, our measure of asset liquidity is larger in terms of economic magnitude and more statistically significant. This is not entirely unexpected as our measure considers all information on the balance sheet while the GKP measure effectively truncates the balance sheet and omits a subset of line items from the calculation.

Column 5 replaces historic industry cash flow volatility with a firm specific measure of cash flow volatility. It is possible that firms with high balance sheet illiquidity will also have relatively high firm specific cash flow volatility. To address this concern, we recalculate cash flow volatility at a firm level. However, the firm specific historic cash flow volatility does not appear to account for the relationship between the balance sheet illiquidity and future cash flow volatility.

The final two columns examine the relationship over two separate sub-periods (1980-1999 and 2000-2018). We find that the relationship between balance sheet illiquidity and future cash flow volatility is negative and highly significant in both sub-periods.

While the findings do not necessarily shed light on why future cash flow volatility increases, they provide a possible justification for why investors may consider a less liquid firm as riskier. Once the balance sheet liquidity has been revealed, investors may adjust their beliefs of future cash flow volatility. This is particularly true if liquidity is a way for managers to take precautions against cash flow volatility. However, while managers will take prior cash flow volatility into consideration, it is the expected future cash flow volatility they will ultimately use to determine the appropriate liquidity position to mitigate cash flow risk. In an efficient market, investors would acknowledge the precautionary actions taken by managers and adjust their beliefs about the future riskiness of a firm's cash flow. 


\section{Robustness Tests}

\section{a. Balance Sheet Illiquidity Excluding Cash}

Much of the literature on balance sheet asset liquidity focuses on the cash ratio. It is possible that our findings are simply a reflection of the cash ratio and not necessarily our more complete measure of balance sheet liquidity. While our previous results have controlled for the cash ratio, we take a further step and omit cash from our measure of balance sheet illiquidity. Portfolio raw returns and five-factor alphas are reported on Panel A of Table 6. These portfolios have been formed based on an updated measure of balance sheet illiquidity which excludes the cash and cash equivalents line item. As with our earlier portfolio results, the spread portfolio earns a negative and significant return over the sample period for both equal-weighted and value-weighted portfolios. We have also considered the risk-adjusted returns and find a similar negative and significant return after adjusting for the five-factors suggested by Fama and French (2015). Magnitude of the returns for the spread portfolios formed based on our illiquidity measure excluding cash is similar to the portfolio return including cash or slightly larger while the statistical significance declines slightly. Given these resultsinclusion of the cash ratio in our measure of balance sheet illiquidity. In addition, the construction of our measure places the least weight on cash and emphasizes the less liquid balance sheet items which have become a more prominent component of balance sheets in more recent years.

We also re-run our Fama MacBeth regressions and report the coefficient and t-stat associated with balance sheet illiquidity after excluding cash on Panel B of Table 6. Our results remain consistent with our previous findings. The coefficient on illiquidity is negative and significant. Combined with our portfolio results, this provides further evidence that the return predictability associated with balance sheet illiquidity is not driven solely by cash holdings. 


\section{b. Changes in Cash Flow Volatility}

To this point our testing focused on the level of future cash flow volatility. It is also possible that the liquidity of the balance sheet may indicate a change in cash flow volatility. To evaluate this possibility, we replace future cash flow volatility with the difference between future cash flow volatility and historic cash flow volatility divided by historic cash flow volatility ${ }^{3}$. The results of these regressions are reported in Table 7. The regressions adopt the same conventions and controls as those discussed in Section 4.

As with our previous findings, the coefficient on balance sheet illiquidity is negatively associated with changes in cash flow volatility and highly significant. Stated differently, more liquid firms are associated with increases in future cash flow volatility relative to historic cash flow volatility. This result is consistent with the notion that managers adjust their balance sheet in anticipation of an increase in future cash flow volatility. Managers are taking precautions to safeguard against anticipated future cash flow volatility. This is also consistent with our portfolio findings to the extent that managers have better information regarding future cash flow volatility. Again, the balance sheet appears to contain useful information about the future performance of the firm. Consistent with managers taking precautionary actions, we find that firms that have more liquid balance sheets tend to experience increases in future cash flow volatility. This provides further evidence that the liquidity of the balance sheet could be informative about the riskiness of future cash flows that managers expect.

\footnotetext{
${ }^{3}$ Results are qualitatively similar if we use the difference between future cash flow volatility and historic cash flow volatility with scaling by historic cash flow volatility. Results are available upon request.
} 


\section{Conclusion}

The balance sheet is an informative component of the financial statements (Cooper et al., 2008; Hirshleifer et al., 2004; Sloan, 1996). Because managers increase liquidity as a hedge against the risk of future cash flow volatility, balance sheet asset liquidity can be informative to investors (Bates et al. 2006). Our results confirm and extend these findings. We find that the liquidity of the balance sheet is associated with subsequent period returns. The liquidity of the balance sheet appears to be informative to investors regarding future cash flow volatility a firm may experience.

We propose a new measure of balance sheet illiquidity. Our measure differs from existing measures in that it considers the composition of the balance sheet as a whole, rather than primarily focusing on cash and aggregating or omitting remaining balance sheet asset line items. Using our measure, we first provide evidence of a link between liquidity and stock returns. Firms that are highly liquid are associated with higher levels of returns. This is consistent with highly liquid firms being riskier. Then we construct decile portfolios based on our measure of illiquidity and generate a statistically significant spread portfolio. This suggests a positive relationship between liquidity

and stock returns. We also find that our results are robust to risk-adjusting using the Fama and French (2015) five-factor model and after controlling for a variety of other common return determinants.

Given the existing literature on precautionary savings and cash flow volatility, we propose that the excess return realized by more liquid firms could, in part, be driven by the fact that managers are taking measures to mitigate future cash flow volatility by adjusting balance sheet asset liquidity. While we do not interpret the relationship between liquidity and future returns as causal, we believe that the liquidity could signal management's beliefs about the riskiness of future cash flows. We regress our measure of illiquidity against future cash flow volatility and 
consistently find that higher liquidity is associated with higher future cash flow volatility. Lastly, we provide evidence that highly liquid firms are associated with increases in cash flow volatility. This is consistent with the notion that managers adjust liquidity to act as precautionary savings against future cash flow volatility, which may signal that cash flow volatility is expected to increase.

This paper provides two main contributions to the literature. First, we propose a simple and holistic measure of illiquidity. Our measure is conceptually consistent with the SEC's requirement that different categories of assets be listed as separate line items. In all regressions, our measure outperforms existing measures. Additionally, our measure has residual explanatory power when existing measures are used as control variables. This suggests that investors consider not just the level of cash, but the composition of the balance sheet as a whole when assessing liquidity. In robustness tests, we show that our results hold even when cash is omitted from our measure of liquidity. Second, we provide evidence that the level of liquidity may also indicate a change in the cash flow volatility. Higher levels of liquidity are associated with both high levels of future cash flow volatility and increases in cash flow volatility. This suggests that the level of liquidity is forward looking in that it signals management's beliefs about future cash flow volatility. Our results are limited in that we do not interpret the link between liquidity and future cash flow volatility as causal. We interpret the liquidity of the balance sheet as a signal of future cash flow volatility. Our return results are robust to the inclusion of a variety of other common determinants of subsequent period returns. 


\section{References}

Acharya, V. V., Almeida, H., \& Campello, M. (2007). Is cash negative debt? A hedging perspective on corporate financial policies. Journal of Financial Intermediation, 16(4), 515-554. doi:https://doi.org/10.1016/j.jfi.2007.04.001

Almeida, H., Campello, M., \& Weisbach, M. S. (2004). The Cash Flow Sensitivity of Cash. The Journal of Finance, 59(4), 1777-1804. doi:10.1111/j.1540-6261.2004.00679.x

Amihud, Y. (2002). Illiquidity and stock returns: cross-section and time-series effects. Journal of Financial Markets, 5(1), 31-56. doi:https://doi.org/10.1016/S1386-4181(01)00024-6

Bates, T. W., Kahle, K. M., \& Stulz, R. M. (2009). Why Do U.S. Firms Hold so Much More Cash than They Used To? The Journal of Finance, 64(5), 1985-2021. Retrieved from www.jstor.org/stable/27735163

Campbell, J. Y., Hilscher, J., \& Szilagyi, J. (2008). In Search of Distress Risk. The Journal of Finance, 63(6), 2899-2939. doi:10.1111/j.1540-6261.2008.01416.x

Carhart, M. M. (1997). On Persistence in Mutual Fund Performance. The Journal of Finance, 52(1), 57-82. doi:10.2307/2329556

Cooper, M. J., Gulen, H., \& Schill, M. J. (2008). Asset Growth and the Cross-Section of Stock Returns. The Journal of Finance, 63(4), 1609-1651. Retrieved from www.jstor.org/stable/25094485

Fama, E. F., \& French, K. R. (1993). Common risk factors in the returns on stocks and bonds. Journal of financial Economics, 33(1), 3-56. doi:https://doi.org/10.1016/0304$\underline{405 X(93) 90023-5}$

Fama, E. F., \& French, K. R. (2015). A five-factor asset pricing model. Journal of financial Economics, 116(1), 1-22. doi:https://doi.org/10.1016/j.jfineco.2014.10.010 
Foley, F. C., Hartzell, J. C., Titman, S., \& Twite, G. (2007). Why do firms hold so much cash? A tax-based explanation. Journal of financial Economics, 86(3), 579-607. doi:https://doi.org/10.1016/j.jfineco.2006.11.006

Gopalan, R., Kadan, O., \& Pevzner, M. (2012). Asset Liquidity and Stock Liquidity. Journal of Financial and Quantitative Analysis, 47(2), 333-364. doi:10.1017/S0022109012000130

Greene, W. H. (2012). Econometric analysis, 71e. Stern School of Business, New York University.

Han, S., \& Qiu, J. (2007). Corporate precautionary cash holdings. Journal of Corporate Finance, 13(1), 43-57. doi:https://doi.org/10.1016/j.jcorpfin.2006.05.002

Hirshleifer, D., Kewei, H., Teoh, S. H., \& Yinglei, Z. (2004). Do investors overvalue firms with bloated balance sheets? Journal of Accounting and Economics, 38, 297-331. doi:https://doi.org/10.1016/j.jacceco.2004.10.002

Lintner, J. (1965). THE VALUATION (OR RISK ASSETS AND THE SELECTION OR RISKY INVESTMENTS IN STOCK PORTROLIOS AND CAPITAL, BUDGETS. The Review of Economics and Statistics, 47(1), 13-37.

Ortiz-Molina, H., \& Phillips, G. M. (2014). Real Asset Illiquidity and the Cost of Capital. Journal of Financial and Quantitative Analysis, 49(1), 1-32. doi:10.1017/S0022109014000210

Pástor, L., \& Stambaugh, Robert F. (2003). Liquidity Risk and Expected Stock Returns. Journal of Political Economy, 111(3), 642-685. doi:10.1086/374184

Sharpe, W. F. (1964). CAPITAL ASSET PRICES: A THEORY OF MARKET EQUILIBRIUM UNDER CONDITIONS OF RISK*. The Journal of Finance, 19(3), 425-442. doi:10.1111/j.1540-6261.1964.tb02865.x 
Sloan, R. G. (1996). Do Stock Prices Fully Reflect Information in Accruals and Cash Flows about Future Earnings? The Accounting Review, 71(3), 289-315. Retrieved from www.jstor.org/stable/248290

Titman, S., Wei, K. C. J., \& Xie, F. (2004). Capital Investments and Stock Returns. The Journal of Financial and Quantitative Analysis, 39(4), 677-700. Retrieved from $\underline{\text { www.jstor.org/stable/30031881 }}$ 
Figure 1 - Balance Sheet Illiquidity and Cash Ratio Over Time

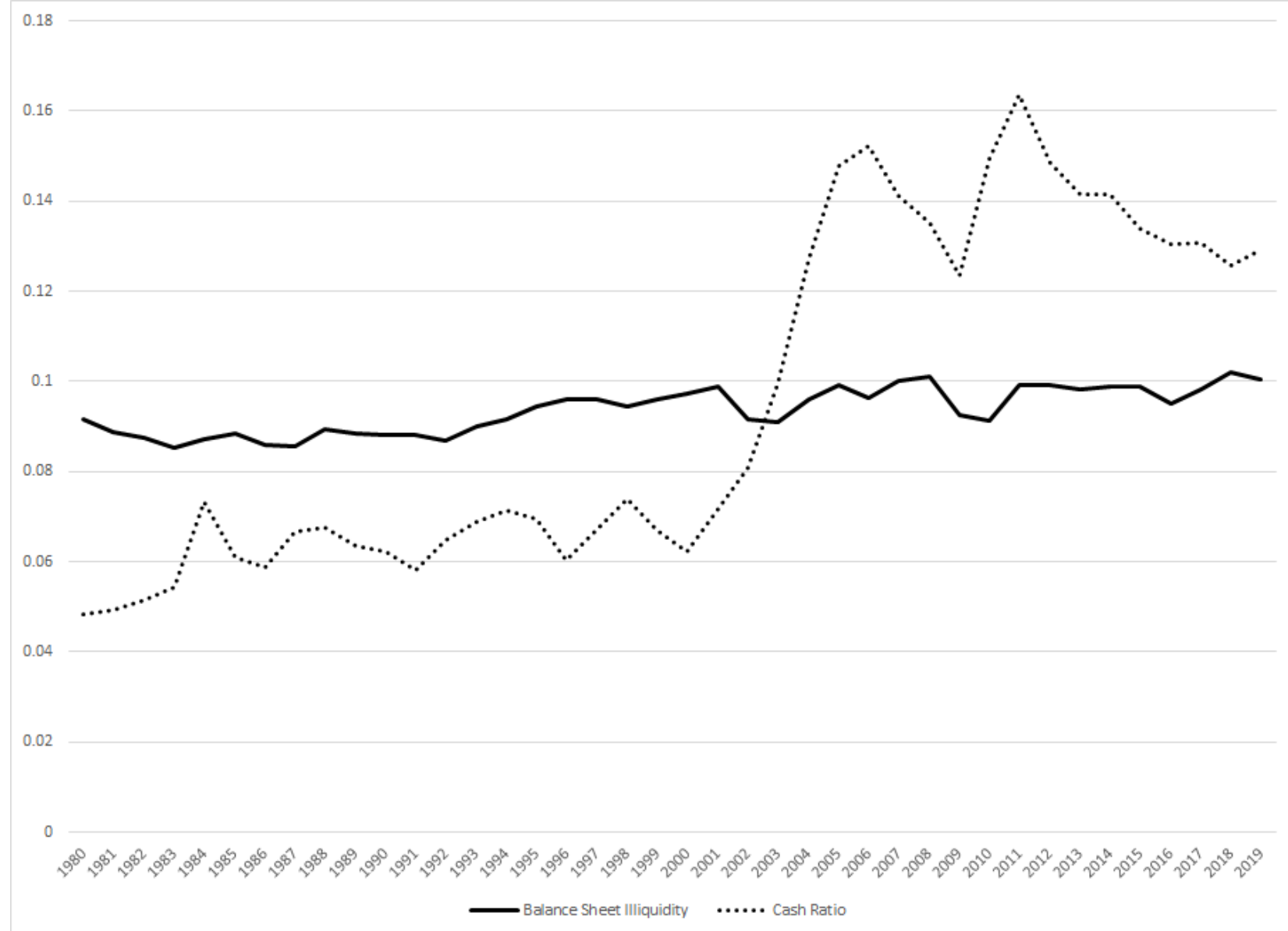

This figure presents the average cash ratio and balance sheet illiquidity for each year from 1980 through 2018. All values are winsorized at the 1 and 99 percentiles. 
Figure 2 - Annual Returns for Balance Sheet Illiquidity Portfolios

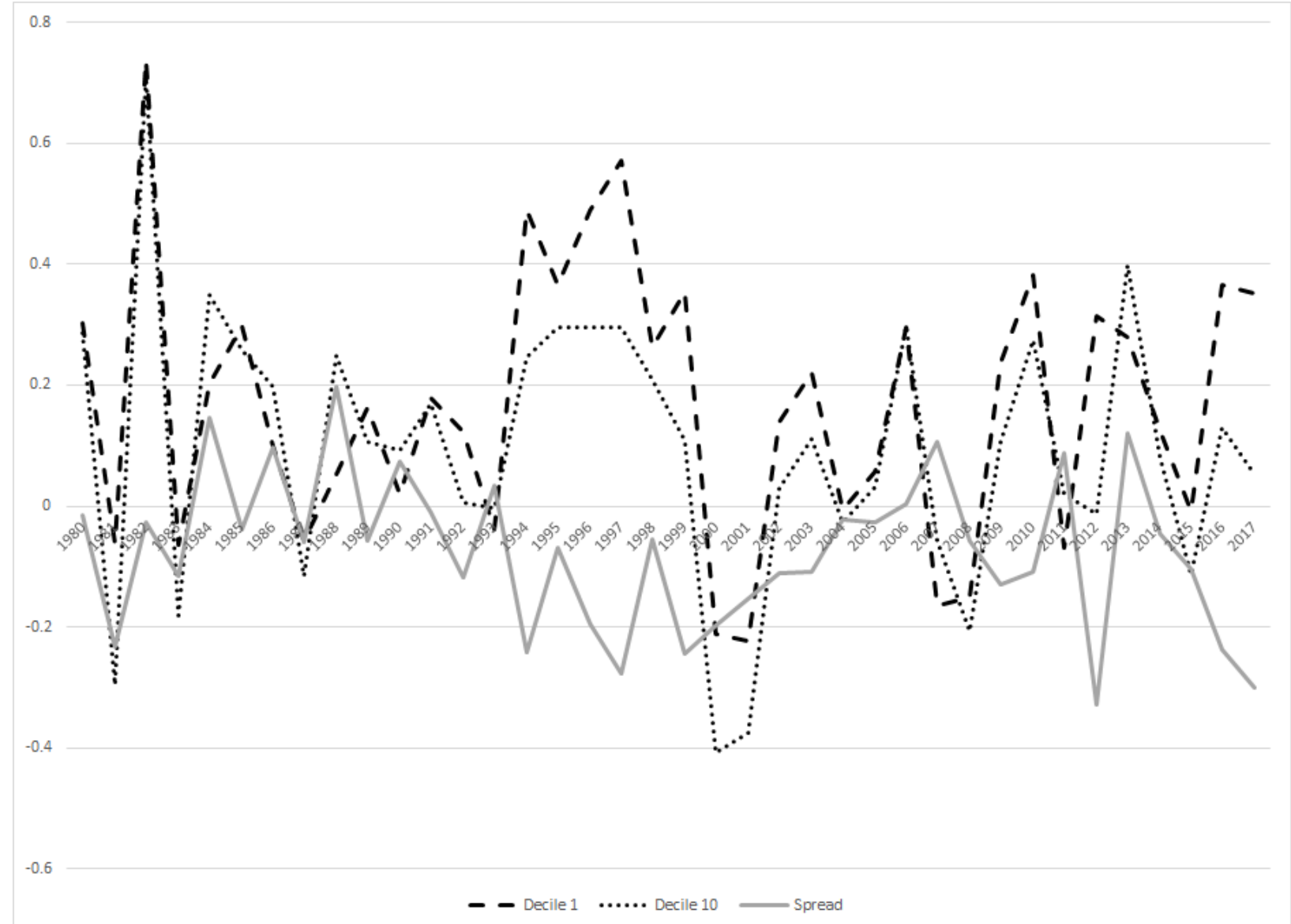

This figure plots the buy-and-hold annual returns for the decile 1, decile 10, and spread portfolios formed based on balance sheet illiquidity. Portfolios are held from the beginning of July or year $t+1$ to the end June of year $t+2$. 


\section{Table 1 - Summary Statistics}

Panel A of this table reports the mean, standard deviation, minimum, and maximum variables used in our cash flow volatility regressions. A full description of all variables can be found in Appendix A. The sample includes all common stock listed on the NYSE, NASDAQ, and AMEX exchanges with a share price exceeding 5 dollars at portfolio formation. We also exclude microcap (bottom $20 \%$ of stocks based on NYSE percentile), financial, and utility firms from our sample. The sample period extends from 1980-2018. Panel B reports the percentage of the balance sheet associated with each component used by Compustat in the calculation of total assets. The percentages are reported by decade as well as for the full sample. The last column reports the difference between the percentages reported in the 1980-1990 column and the 2010-2018 column. All variables are winsorized at the $1^{\text {st }}$ and $99^{\text {th }}$ percentiles.

\section{Panel A}

\begin{tabular}{lrcccc} 
Summary Statistics & N & Mean & Std. Dev. & Min & Max \\
\hline Illiquidity & 98,074 & 0.0985 & 0.0401 & 0.0256 & 0.2856 \\
GKP Weighted Asset Liquidity & 86,489 & 0.6756 & 0.2524 & 0.2110 & 1.8344 \\
Historic Cash Flow Volatility & 88,057 & 0.0781 & 0.0914 & 0.0062 & 0.5692 \\
Industry Cash Flow Volatility & 105,640 & 0.0879 & 0.0480 & 0.0220 & 0.2774 \\
Market to Book & 104,968 & 1.8178 & 1.3712 & 0.5554 & 8.6465 \\
Real Size & 105,664 & 5.4215 & 2.2352 & 0.9298 & 10.7234 \\
Capital Expenditures & 104,521 & 0.0574 & 0.0588 & 0.0001 & 0.3215 \\
Cash Ratio & 105,657 & 0.1652 & 0.1955 & 0.0005 & 0.8709 \\
Change in Cash Ratio & 98,065 & -0.0010 & 0.0827 & -0.2857 & 0.2825 \\
R\&D to Sales & 104,332 & 0.1230 & 0.5215 & 0.0000 & 4.1115 \\
Net Working Capital & 102,725 & 0.2713 & 0.2359 & -0.3681 & 0.8329 \\
Leverage & 102,998 & 0.4347 & 0.2296 & 0.0436 & 1.2154 \\
Cash Flows & 99,752 & 0.0427 & 0.1907 & -0.8995 & 0.3393
\end{tabular}

\section{Panel B}

\section{Percent of Total Assets over Time}

Asset Description

Current Assets

Cash and Short-Term Investments

Receivables

Inventories

Current Assets - Other

Total Current Assets

\section{Compustat}

Label

1

Full Sample 1980-1990 1991-2000 2001-2010 2010-2018 Change

$\begin{array}{ccccccc}\text { CHE } & 0.1396 & 0.0981 & 0.1209 & 0.1736 & 0.1773 & 0.0792 \\ \text { RECT } & 0.1679 & 0.1942 & 0.1839 & 0.1495 & 0.1331 & -0.0611 \\ \text { INVT } & 0.1476 & 0.1969 & 0.1500 & 0.1224 & 0.1102 & -0.0867 \\ \text { ACO } & 0.0321 & 0.0231 & 0.0331 & 0.0381 & 0.0350 & 0.0119 \\ & 0.4872 & 0.5123 & 0.4879 & 0.4837 & 0.4557 & -0.0566\end{array}$

Long Term Assets

\begin{tabular}{lccccccc}
\hline Property, Plant and Equipment (Net) & PPENT & 0.3248 & 0.3885 & 0.3482 & 0.2791 & 0.2652 & -0.1234 \\
Other Investments & IVAO & 0.0237 & 0.0256 & 0.0259 & 0.0225 & 0.0197 & -0.0059 \\
Investments in Equity & IVAEQ & 0.0114 & 0.0162 & 0.0109 & 0.0089 & 0.0090 & -0.0073 \\
Intangibles & INTAN & 0.1034 & 0.0248 & 0.0636 & 0.1520 & 0.2047 & 0.1799 \\
Other Assets & AO & 0.0494 & 0.0325 & 0.0636 & 0.0540 & 0.0457 & 0.0132 \\
Total Long Term Assets & & 0.5128 & 0.4877 & 0.5121 & 0.5165 & 0.5443 & 0.0566
\end{tabular}




\section{Table 2 - Decile Portfolio Raw Returns}

This table reports the portfolio raw returns to portfolios formed based on the prior year's balance sheet illiquidity. Firms are assigned to decile portfolios at the end of June of each year from 1980-2017 based on balance sheet illiquidity from fiscal year $t$ - 1 . These portfolios are held from the end of June of year $t$ to the end of June of year $t+1$. Portfolios are then reformed. Panel A reports the average monthly equalweighted and value-weighted raw returns to each decile portfolio over the sample period as well as average monthly returns for size terciles. Panel B reports the average monthly returns across two separate sub-periods (1980-1999 and 2000-2018). In addition to individual portfolio returns, we report returns earned by a spread portfolio formed by buying portfolio 10 and selling portfolio 1 . The t-statistic is associated with the spread portfolio. All numbers, excluding t-statistics, are in decimal form, where 0.01 is equal to $1 \%$.

\section{Panel A}

\begin{tabular}{|c|c|c|c|c|c|c|c|c|c|c|c|c|}
\hline \multicolumn{13}{|c|}{ Equal Weighted } \\
\hline & 1 & 2 & 3 & 4 & 5 & 6 & 7 & 8 & 9 & 10 & Spread & t-Stat \\
\hline All Firms & 0.0093 & 0.0095 & 0.0090 & 0.0083 & 0.0089 & 0.0088 & 0.0071 & 0.0075 & 0.0082 & 0.0046 & -0.0046 & -3.66 \\
\hline Small Firms & 0.0092 & 0.0098 & 0.0103 & 0.0096 & 0.0071 & 0.0102 & 0.0084 & 0.0076 & 0.0084 & 0.0054 & -0.0037 & -1.91 \\
\hline Medium Firms & 0.0094 & 0.0093 & 0.0086 & 0.0091 & 0.0084 & 0.0091 & 0.0076 & 0.0080 & 0.0095 & 0.0043 & -0.0052 & -3.03 \\
\hline Large Firms & 0.0090 & 0.0088 & 0.0087 & 0.0082 & 0.0075 & 0.0080 & 0.0071 & 0.0059 & 0.0075 & 0.0043 & -0.0048 & -3.33 \\
\hline
\end{tabular}

\begin{tabular}{|c|c|c|c|c|c|c|c|c|c|c|c|c|}
\hline \multicolumn{13}{|c|}{ Value Weighted } \\
\hline & 1 & 2 & 3 & 4 & 5 & 6 & 7 & 8 & 9 & 10 & Spread & t-Stat \\
\hline All Firms & 0.0094 & 0.0090 & 0.0078 & 0.0076 & 0.0077 & 0.0069 & 0.0063 & 0.0055 & 0.0077 & 0.0037 & -0.0057 & -3.33 \\
\hline Small Firms & 0.0091 & 0.0093 & 0.0100 & 0.0095 & 0.0073 & 0.0099 & 0.0085 & 0.0075 & 0.0080 & 0.0056 & -0.0035 & -1.78 \\
\hline Medium Firms & 0.0094 & 0.0092 & 0.0087 & 0.0089 & 0.0086 & 0.0091 & 0.0075 & 0.0079 & 0.0095 & 0.0042 & -0.0052 & -2.97 \\
\hline Large Firms & 0.0100 & 0.0071 & 0.0079 & 0.0078 & 0.0064 & 0.0069 & 0.0061 & 0.0049 & 0.0076 & 0.0043 & -0.0057 & -3.20 \\
\hline
\end{tabular}

\section{Panel B}

\begin{tabular}{|c|c|c|c|c|c|c|c|c|c|c|c|c|}
\hline \multicolumn{13}{|c|}{ Equal Weighted } \\
\hline Sub-period & 1 & 2 & 3 & 4 & 5 & 6 & 7 & 8 & 9 & 10 & Spread & t-Stat \\
\hline 1980-1999 & 0.0094 & 0.0097 & 0.0086 & 0.0089 & 0.0091 & 0.0083 & 0.0063 & 0.0073 & 0.0080 & 0.0047 & -0.0047 & -3.33 \\
\hline $2000-2018$ & 0.0091 & 0.0093 & 0.0094 & 0.0076 & 0.0087 & 0.0093 & 0.0080 & 0.0076 & 0.0083 & 0.0046 & -0.0045 & -2.12 \\
\hline
\end{tabular}

\section{Sub-period}

1980-1999

2000-2018

$\begin{array}{ll}0.0114 & 0.0113 \\ 0.0073 & 0.006\end{array}$

Value Weighted

$\begin{array}{llllllllll}0.0093 & 0.0103 & 0.0100 & 0.0088 & 0.0074 & 0.0077 & 0.0084 & 0.0077 & -0.0037 & -1.78 \\ 0.0062 & 0.0049 & 0.0052 & 0.0049 & 0.0052 & 0.0032 & 0.0071 & -0.0007 & -0.0079 & -2.83\end{array}$




\section{Table 3 - Decile Portfolio Five Factor Alphas}

This table reports the portfolio five-factor alphas for portfolios formed based on the prior year's balance sheet illiquidity. We have used the five-factor model of Fama and French (2015). Firms are assigned to decile portfolios at the end of June of each year from 1980-2017 based on balance sheet illiquidity from fiscal year $\mathrm{t}-1$. These portfolios are held from the end of June of year $\mathrm{t}$ to the end of June of year $\mathrm{t}+1$. Portfolios are then reformed. Panel A reports the alpha for equal-weighted and value-weighted raw returns for each decile portfolio over the sample period as well as the five-factor alpha across size terciles. Panel B reports the five-factor alphas across two separate sub-periods (1980-1999 and 2000-2018). In addition to individual portfolio alphas, we report five-factor alphas earned by a spread portfolio formed by buying portfolio 10 and selling portfolio 1 . The t-statistic is associated with the spread portfolio are heteroskedasticity consistent following White (1980). All numbers, excluding t-statistics, are in decimal form, where 0.01 is equal to $1 \%$.

\section{Panel A}

\begin{tabular}{|c|c|c|c|c|c|c|c|c|c|c|c|c|}
\hline \multicolumn{13}{|c|}{ Equal Weighted } \\
\hline & 1 & 2 & 3 & 4 & 5 & 6 & 7 & 8 & 9 & 10 & Spread & t-Stat \\
\hline All Firms & 0.0027 & 0.0010 & -0.0002 & -0.0011 & -0.0006 & -0.0010 & -0.0015 & -0.0004 & 0.0009 & -0.0031 & -0.0058 & -4.97 \\
\hline Small Firms & 0.0027 & 0.0001 & 0.0004 & -0.0004 & -0.0025 & 0.0002 & -0.0018 & -0.0017 & 0.0004 & -0.0025 & -0.0052 & -2.46 \\
\hline Medium Firms & 0.0040 & 0.0008 & -0.0007 & -0.0009 & -0.0018 & -0.0009 & -0.0018 & -0.0007 & 0.0019 & -0.0036 & -0.0076 & -4.56 \\
\hline Large Firms & 0.0030 & 0.0008 & 0.0006 & -0.0005 & -0.0014 & -0.0001 & -0.0007 & -0.0009 & 0.0009 & -0.0030 & -0.0060 & -4.27 \\
\hline
\end{tabular}

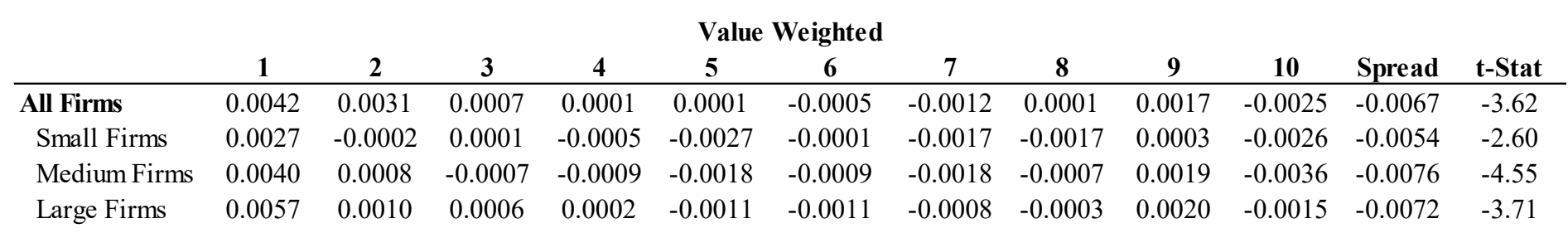

\section{Panel B}

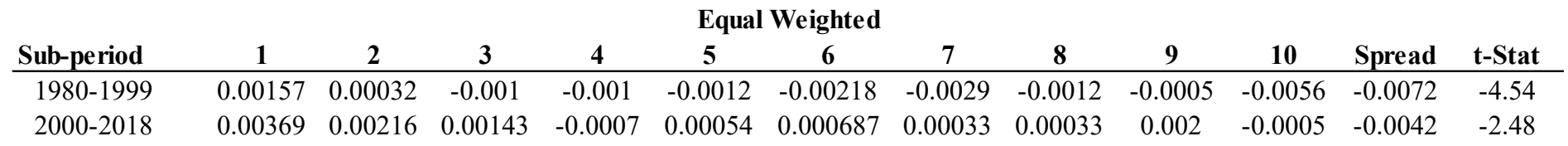

Sub-period

\begin{tabular}{ccccccccccccc}
\hline $1980-1999$ & 0.0037 & 0.0052 & 0.0021 & 0.0007 & -0.0004 & -0.0009 & -0.0024 & -0.0014 & -0.0007 & -0.0026 & -0.0063 & -2.85 \\
$2000-2018$ & 0.0043 & 0.0017 & 0.0008 & -0.0008 & 0.0005 & 0.0000 & 0.0001 & 0.0002 & 0.0036 & -0.0027 & -0.0070 & -2.54
\end{tabular}




\section{Table 4 - Fama-MacBeth Return Regressions on BS Illiquidity and Other Common Return Determinants}

Panel A of this table presents the coefficients and t-statistics from Fama-MacBeth regression of monthly stock returns on lagged accounting and return variables. Accounting control variables include the cash ratio, market to book ratio, capital expenditures, return on assets, and an alternative measure of asset liquidity. The alternative measures of asset liquidity are the cash ratio as in Bates, Kahle, and Stulz (2009) and the weighted asset liquidity measures detailed in equations (2), (3), and (4), respectively. Return based control variables include market capitalization (size), lagged one month returns, and momentum calculated as compound returns from $t$ - 1 through $t$ 12. A complete description of all returns is reported in Appendix A. Panel B presents the coefficients and t-statistics from Fama-MacBeth regressions of monthly stock returns on lagged accounting and return variables across subperiods and size terciles. For the purposes of these regressions, the cash ratio replaces the alternative liquidity measures. All t-statistics are adjusted for five lags following Greene (2012).

\section{Panel A}

\begin{tabular}{lcccc}
\hline & $(1)$ & $(2)$ & $(3)$ & $(4)$ \\
VARIABLES & Cash Ratio & GKP 1 & GKP 2 & GKP 3 \\
\hline & & & & \\
Balance Sheet Illiquidity & $-0.0210^{* * *}$ & $-0.0199^{* * *}$ & $-0.0135^{*}$ & $-0.0204^{* * *}$ \\
Alternative Liquidity Measure & -3.40 & -3.08 & -1.66 & -3.10 \\
& 0.0021 & -0.0008 & -0.0021 & -0.0024 \\
Capital Expenditure & 0.50 & -0.35 & -0.92 & -0.93 \\
Market to Book & -0.0079 & -0.0091 & $-0.0113^{*}$ & $-0.0119^{* *}$ \\
& -1.35 & -1.49 & -1.81 & -2.01 \\
Market Capitalization & $-0.0003^{*}$ & $-0.0003 * *$ & $-0.0002^{*}$ & $-0.0002^{*}$ \\
& -1.94 & -2.03 & -1.72 & -1.66 \\
Return on Assets & -0.0003 & -0.0004 & -0.0004 & -0.0004 \\
Reversal (Prior Month Returns) & -0.48 & -0.55 & -0.63 & -0.55 \\
Momentum & $0.0058^{*}$ & $0.0073 * *$ & $0.0073 *$ & 0.0053 \\
Amihud Illiquidity & 1.94 & 2.26 & 1.95 & 1.56 \\
Constant & -0.0014 & -0.0018 & -0.0014 & -0.0011 \\
& -0.33 & -0.42 & -0.34 & -0.25 \\
Observations & 0.0009 & 0.0009 & 0.0014 & 0.0014 \\
R-squared & 0.77 & 0.78 & 1.15 & 1.12 \\
Standard & 7.2577 & 10.4134 & 10.1866 & 10.5754
\end{tabular}

Standard errors in parentheses $* * * \mathrm{p}<0.01, * * \mathrm{p}<0.05, * \mathrm{p}<0.1$ 
Table 4 (Continued)

Panel B

\begin{tabular}{|c|c|c|c|c|c|}
\hline VARIABLES & $\begin{array}{c}(1) \\
1980-1999 \\
\end{array}$ & $\begin{array}{c}(2) \\
\mathbf{2 0 0 0 - 2 0 1 8} \\
\end{array}$ & $\begin{array}{c}(3) \\
\text { Small }\end{array}$ & $\begin{array}{c}(4) \\
\text { Medium }\end{array}$ & $\begin{array}{c}(5) \\
\text { Large }\end{array}$ \\
\hline Balance Sheet Illiquidity & $\begin{array}{c}-0.0272 * * * \\
-2.99\end{array}$ & $\begin{array}{c}-0.0144^{*} \\
-1.76\end{array}$ & $\begin{array}{c}-0.0208^{*} \\
-1.77\end{array}$ & $\begin{array}{c}-0.0297 * * * \\
-3.17\end{array}$ & $\begin{array}{c}-0.0108 \\
-1.20\end{array}$ \\
\hline Alternative Liquidity Measure & $\begin{array}{c}0.001 \\
0.19\end{array}$ & $\begin{array}{c}0.0032 \\
0.56\end{array}$ & $\begin{array}{c}-0.0013 \\
-0.31\end{array}$ & $\begin{array}{c}0.0006 \\
0.13\end{array}$ & $\begin{array}{c}0.0084 * * \\
1.99\end{array}$ \\
\hline Capital Expenditure & $\begin{array}{c}-0.0122^{* *} \\
-2.03\end{array}$ & $\begin{array}{c}-0.0034 \\
-0.34\end{array}$ & $\begin{array}{c}-0.0092 \\
-1.29\end{array}$ & $\begin{array}{c}-0.0147^{* *} \\
-2.32\end{array}$ & $\begin{array}{l}-0.003 \\
-0.38\end{array}$ \\
\hline Market to Book & $\begin{array}{c}-0.0005^{* *} \\
-1.97\end{array}$ & $\begin{array}{c}0.0000 \\
-0.23\end{array}$ & $\begin{array}{c}-0.0003 \\
-1.56\end{array}$ & $\begin{array}{c}-0.0002 \\
-0.89\end{array}$ & $\begin{array}{c}-0.0001 \\
-0.31\end{array}$ \\
\hline Market Capitalization & $\begin{array}{c}0.0006 \\
0.90\end{array}$ & $\begin{array}{c}-0.0013 \\
-1.16\end{array}$ & $\begin{array}{c}-0.0024 \\
-1.26\end{array}$ & $\begin{array}{c}-0.0012 \\
-0.71\end{array}$ & $\begin{array}{c}-0.0009 \\
-1.11\end{array}$ \\
\hline Return on Assets & $\begin{array}{c}0.0102^{* *} \\
2.15\end{array}$ & $\begin{array}{c}0.001 \\
0.33\end{array}$ & $\begin{array}{c}0.0099 * * * \\
2.68\end{array}$ & $\begin{array}{c}0.0062 \\
1.43\end{array}$ & $\begin{array}{c}0.0008 \\
0.19\end{array}$ \\
\hline Reversal (Prior Month Returns) & $\begin{array}{c}0.0049 \\
0.86\end{array}$ & $\begin{array}{l}-0.008 \\
-1.36\end{array}$ & $\begin{array}{c}-0.0014 \\
-0.27\end{array}$ & $\begin{array}{c}-0.0019 \\
-0.37\end{array}$ & $\begin{array}{l}-0.006 \\
-1.03\end{array}$ \\
\hline Momentum & $\begin{array}{c}0.0031^{*} \\
1.93\end{array}$ & $\begin{array}{c}-0.0014 \\
-0.84\end{array}$ & $\begin{array}{c}0.0003 \\
0.21\end{array}$ & $\begin{array}{c}0.0023 \\
1.52\end{array}$ & $\begin{array}{c}0.0013 \\
0.75\end{array}$ \\
\hline Amihud Illiquidity & $\begin{array}{c}3.0472 \\
0.45\end{array}$ & $\begin{array}{c}11.6899 \\
0.22\end{array}$ & $\begin{array}{c}14.5277 \\
0.71\end{array}$ & $\begin{array}{c}16.5454 \\
0.71\end{array}$ & $\begin{array}{c}27.2575 \\
0.29\end{array}$ \\
\hline Constant & $\begin{array}{c}0.0076 \\
0.66\end{array}$ & $\begin{array}{c}0.0284 \\
1.40\end{array}$ & $\begin{array}{c}0.0437^{*} \\
1.68\end{array}$ & $\begin{array}{c}0.0304 \\
1.21\end{array}$ & $\begin{array}{c}0.0263^{*} \\
1.72\end{array}$ \\
\hline $\begin{array}{l}\text { Observations } \\
\text { R-squared }\end{array}$ & $\begin{array}{c}216,473 \\
0.057 \\
\end{array}$ & $\begin{array}{c}226,573 \\
0.072 \\
\end{array}$ & $\begin{array}{c}133,455 \\
0.082 \\
\end{array}$ & $\begin{array}{c}142,601 \\
0.093 \\
\end{array}$ & $\begin{array}{c}166,570 \\
0.108 \\
\end{array}$ \\
\hline
\end{tabular}

Standard errors in parentheses

$* * * \mathrm{p}<0.01, * * \mathrm{p}<0.05, * \mathrm{p}<0.1$ 


\section{Table 5 - Regressions of Illiquidity on Future Cash Flow Volatility}

This table presents regression results of future cash flow volatility on balance sheet illiquidity and a variety of control variables. Following Bates, Kahle, and Stulz (2009), we calculate cash flow volatility as the standard deviation of cash flow, where cash flow is earnings before interest and tax plus depreciation less interest and common dividends scaled by total assets. In addition to our measure of balance sheet illiquidity, we have included controls for GKP weighted asset liquidity, historic measures of cash flow volatility (both industry and firm level), market to book, natural log of total assets, capital expenditures, cash ratio, change in the cash ratio, research and development expenditure to sales, net working capital, leverage, and cash flow. Additional detail regarding the construction of the control variables is available in Appendix A. The sample includes all common stocks listed on the NYSE, NASDAQ, and AMEX stock exchanges excluding microcap stocks and securities with a price below 5 dollars. The sample period is from 19802018. Columns 1-5 include all years in the regressions. Columns 6 and 7 test the relationship between future cash flow volatility and balance sheet illiquidity over the sub-periods 1980-1999 and 2000-2018, respectively. We have also included firm fixed effects and clustered standard errors at the industry level. We follow the Fama-French 49 industry definitions.

\begin{tabular}{|c|c|c|c|c|c|c|c|}
\hline \multirow[b]{2}{*}{ VARIABLES } & (1) & (2) & $(3)$ & (4) & (5) & (6) & (7) \\
\hline & \multicolumn{7}{|c|}{ Forward Cash Flow Volatility } \\
\hline & & & & & & 1980-1999 & $2000-2018$ \\
\hline \multirow[t]{2}{*}{ Illiquidity } & $-0.0712 * * *$ & $-0.0680 * * *$ & $-0.0683 * * *$ & $-0.1389 * * *$ & $-0.0491 * *$ & $-0.0425 * * *$ & $-0.0840^{* * *}$ \\
\hline & -3.80 & -4.09 & -4.04 & -2.75 & -2.66 & -3.70 & -3.08 \\
\hline \multirow[t]{2}{*}{ GKP Weighted Asset Liquidity } & & & & $0.0150 *$ & & & \\
\hline & & & & 1.80 & & & \\
\hline \multirow[t]{2}{*}{ Historic Cash Flow Volatility } & & & & & $-0.2957 * * *$ & & \\
\hline & & & & & -8.26 & & \\
\hline \multirow[t]{2}{*}{ Industry Cash Flow Volatility } & & $-0.1093 * *$ & $-0.0995 * *$ & $-0.0971 *$ & & $-0.1583 * *$ & -0.0928 \\
\hline & & -2.30 & -2.08 & -1.94 & & -2.54 & -1.50 \\
\hline \multirow[t]{2}{*}{ Market to Book } & & 0.0005 & 0.0007 & 0.0007 & $0.0019 * *$ & 0.0007 & 0.0004 \\
\hline & & 0.50 & 0.74 & 0.92 & 2.47 & 0.77 & 0.35 \\
\hline \multirow[t]{2}{*}{ Total Assets } & & -0.0003 & -0.0003 & 0.0006 & -0.0037 & 0.0026 & 0.0033 \\
\hline & & -0.10 & -0.11 & 0.18 & -1.22 & 1.59 & 0.72 \\
\hline \multirow[t]{2}{*}{ Capital Expenditures } & & & $0.0339 * * *$ & $0.0270 * *$ & $0.0402 * *$ & -0.0055 & $0.0398 * *$ \\
\hline & & & 2.89 & 2.18 & 2.62 & -0.47 & 2.25 \\
\hline \multirow[t]{2}{*}{ Cash Ratio } & & & 0.0012 & -0.0120 & 0.0113 & 0.0082 & -0.0052 \\
\hline & & & 0.15 & -1.12 & 1.47 & 1.03 & -0.61 \\
\hline \multirow[t]{2}{*}{ Change in Cash Ratio } & & & 0.0039 & 0.0014 & 0.0030 & -0.0003 & 0.0065 \\
\hline & & & 0.99 & 0.34 & 0.74 & -0.06 & 1.33 \\
\hline \multirow[t]{2}{*}{ R\&D to Sales } & & & $0.0161 * * *$ & $0.0156^{* * *}$ & $0.0138 * * *$ & $0.0079 * * *$ & $0.0137^{* *}$ \\
\hline & & & 3.96 & 3.48 & 2.92 & 3.53 & 2.67 \\
\hline \multirow[t]{2}{*}{ Net working capital } & & & -0.0019 & -0.0061 & -0.0035 & $-0.0159 * * *$ & 0.0001 \\
\hline & & & -0.39 & -0.70 & -0.76 & -2.81 & 0.01 \\
\hline \multirow[t]{2}{*}{ Leverage } & & & -0.0079 & -0.0065 & 0.0000 & $-0.0221 * *$ & 0.0008 \\
\hline & & & -1.25 & -0.81 & 0.01 & -2.40 & 0.08 \\
\hline \multirow[t]{2}{*}{ Cash Flow } & & & -0.0062 & -0.0126 & $-0.0227 * * *$ & $0.0180 *$ & -0.0076 \\
\hline & & & -0.67 & -1.38 & -2.78 & 1.90 & -0.52 \\
\hline \multirow[t]{2}{*}{ Intercept } & $0.0923 * * *$ & $0.0984^{* * *}$ & $0.0960 * * *$ & $0.0897 * * *$ & $0.1140^{* * *}$ & $0.0920 * * *$ & $0.0798 * * *$ \\
\hline & 35.45 & 7.87 & 8.25 & 7.26 & 8.67 & 9.20 & 2.90 \\
\hline Fixed Effects & Firm & Firm & Firm & Firm & Firm & Firm & Firm \\
\hline Clusters & Industry & Industry & Industry & Industry & Industry & Industry & Industry \\
\hline Observations & 70,929 & 70,462 & 65,187 & 58,563 & 60,147 & 34,585 & 30,602 \\
\hline
\end{tabular}


Table 6 - Decile Portfolio Returns Formed Based on Balance Sheet Illiquidity Excluding Cash

This table reports the portfolio raw returns to portfolios formed based on the prior year's balance sheet illiquidity excluding cash. Firms are assigned to decile portfolios at the end of June of each year from 1980-2017 based on balance sheet illiquidity from fiscal year $t-1$. These portfolios are held from the end of June of year $t$ to the end of June of year $t+1$ Portfolios are then reformed. Panel A reports the average monthly equal-weighted and value-weighted raw returns to each decile portfolio over the sample period as well as equalweighted and value-weighted five-factor alphas for each decile portfolio. In addition, we have reported spread portfolio returns and associated t-statistics. Panel B reports the coefficient from Fama-MacBeth regressions of monthly returns on balance sheet illiquidity and the same set of controls used in the first regression on Table 4. In addition to the full sample, we also report the coefficient from the Fama-MacBeth regressions over the two sub-periods, 1980-1999 and 2000-2018. All portfolio returns are in decimal form, where 0.01 is equal to $1 \%$. The t-statistics for the Fama-MacBeth regressions are Newey-West adjusted for five lags.

Panel A

\section{Raw Returns}

\begin{tabular}{|c|c|c|c|c|c|c|c|c|c|c|c|c|}
\hline & 1 & 2 & 3 & 4 & 5 & 6 & 7 & 8 & 9 & 10 & Spread & t-Stat \\
\hline Equal Weighted & 0.0093 & 0.0091 & 0.0088 & 0.0086 & 0.0090 & 0.0093 & 0.0082 & 0.0069 & 0.0082 & 0.0047 & -0.0046 & -3.07 \\
\hline Value Weighted & 0.0104 & 0.0078 & 0.0087 & 0.0072 & 0.0079 & 0.0079 & 0.0068 & 0.0059 & 0.0082 & 0.0043 & -0.0061 & -2.86 \\
\hline
\end{tabular}

Five-Factor Alphas

\begin{tabular}{|c|c|c|c|c|c|c|c|c|c|c|c|c|}
\hline & 1 & 2 & 3 & 4 & 5 & 6 & 7 & 8 & 9 & 10 & Spread & t-Sta \\
\hline Equal Weighted & 0.0036 & 0.0011 & 0.0002 & -0.0009 & -0.0009 & -0.0004 & -0.0019 & -0.0027 & -0.0008 & -0.0039 & -0.0075 & -5.60 \\
\hline Value Weighted & 0.0061 & 0.0028 & 0.0028 & -0.0005 & -0.0058 & 0.0009 & -0.0005 & -0.0013 & 0.0007 & -0.0019 & -0.0080 & -3.42 \\
\hline
\end{tabular}

Panel B

Fama MacBeth

\begin{tabular}{lccc} 
& $(1)$ & $(2)$ & $(3)$ \\
& $1980-2018$ & $1980-1999$ & $1999-2018$ \\
\hline Illiquidity & $-0.0176^{* * *}$ & $-0.0218^{* * *}$ & $-0.0132^{*}$ \\
t-Stat & -3.31 & -2.72 & -1.91 \\
& & & \\
Controls & $\mathrm{Y}$ & $\mathrm{Y}$ & $\mathrm{Y}$
\end{tabular}




\section{Table 7 - Regressions of Illiquidity on Change in Cash Flow Volatility}

This table presents regression results of the change in cash flow volatility on balance sheet illiquidity and a variety of control variables. Following Bates, Kahle, and Stulz (2009), we calculate cash flow volatility as the standard deviation of cash flow, where cash flow is earnings before interest and tax plus depreciation less interest and common dividends scaled by total assets. The change in cash flow volatility is calculated as the difference between firm level historic cash flow volatility and future cash flow volatility. In addition to our measure of balance sheet illiquidity, we have included controls for GKP weighted asset liquidity, historic measures of cash flow volatility (both industry and firm level), market to book, natural log of total assets, capital expenditures, cash ratio, change in the cash ratio, research and development expenditure to sales, net working capital, leverage, and cash flow. Additional detail regarding the construction of the control variables is available in Appendix A. The sample includes all common stocks listed on the NYSE, NASDAQ, and AMEX stock exchanges excluding microcap stocks and securities with a price below 5 dollars The sample period is from 1980-2018. Columns 1-5 include all years in the regressions. Columns 6 and 7 test the relationship between changes in cash flow volatility and balance sheet illiquidity over the sub-periods 1980-1999 and 2000-2018, respectively. We have also included firm fixed effects and clustered standard errors at the industry level. We follow the Fama-French 49 industry definitions.

\begin{tabular}{|c|c|c|c|c|c|c|c|}
\hline \multirow{2}{*}{ VARIABLES } & (1) & (2) & (3) & (4) & $(5)$ & (6) & (7) \\
\hline & \multicolumn{7}{|c|}{ Change in Cash Flow Volatility } \\
\hline & & & & & & 1980-1999 & $2000-2018$ \\
\hline \multirow[t]{2}{*}{ Illiquidity } & $-0.7140 * * *$ & $-0.4769 * * *$ & $-0.5040 * * *$ & $-1.1696 * * *$ & $-0.3480 * * *$ & $-0.3885^{* *}$ & $-0.4631 * *$ \\
\hline & -4.38 & -3.76 & -5.31 & -4.21 & -3.16 & -2.44 & -2.47 \\
\hline \multirow[t]{2}{*}{ GKP Weighted Asset Liquidity } & & & & $0.1519 * * *$ & & & \\
\hline & & & & 2.75 & & & \\
\hline \multirow[t]{2}{*}{ Historic Cash Flow Volatility } & & & & & $-2.8173 * * *$ & & \\
\hline & & & & & -8.67 & & \\
\hline \multirow[t]{2}{*}{ Industry Cash Flow Volatility } & & $-2.5581 * * *$ & $-2.4323 * * *$ & $-2.3458 * * *$ & & $-2.4028 * * *$ & $-1.6021 * * *$ \\
\hline & & -6.43 & -6.50 & -6.28 & & -3.41 & -3.22 \\
\hline \multirow[t]{2}{*}{ Market to Book } & & 0.0027 & 0.0048 & 0.0043 & $0.0149 * *$ & 0.0040 & -0.0015 \\
\hline & & 0.40 & 0.75 & 0.74 & 2.70 & 0.49 & -0.21 \\
\hline \multirow[t]{2}{*}{ Total Assets } & & $-0.0486 * * *$ & $-0.0507 * * *$ & $-0.0451 * *$ & $-0.0830 * * *$ & 0.0014 & $-0.0399 *$ \\
\hline & & -3.19 & -3.34 & -2.54 & -4.71 & 0.06 & -1.81 \\
\hline \multirow[t]{2}{*}{ Capital Expenditures } & & & $0.2135^{* *}$ & 0.1382 & $0.3266^{* * *}$ & -0.0890 & $0.3222 *$ \\
\hline & & & 2.21 & 1.32 & 3.14 & -0.68 & 1.78 \\
\hline \multirow[t]{2}{*}{ Cash Ratio } & & & 0.0465 & -0.0850 & $0.1307^{*}$ & 0.0520 & 0.0336 \\
\hline & & & 0.67 & -1.15 & 1.90 & 0.57 & 0.33 \\
\hline \multirow[t]{2}{*}{ Change in Cash Ratio } & & & -0.0067 & -0.0240 & -0.0164 & -0.0022 & 0.0329 \\
\hline & & & -0.16 & -0.52 & -0.34 & -0.04 & 0.45 \\
\hline \multirow[t]{2}{*}{ R\&D to Sales } & & & $0.0789 *$ & 0.0783 & 0.0621 & $0.0762 * * *$ & 0.0624 \\
\hline & & & 1.76 & 1.60 & 1.27 & 2.96 & 1.21 \\
\hline \multirow[t]{2}{*}{ Net working capital } & & & -0.0378 & -0.0812 & -0.0335 & $-0.1758 * *$ & -0.0639 \\
\hline & & & -0.68 & -1.01 & -0.63 & -2.66 & -0.71 \\
\hline \multirow[t]{2}{*}{ Leverage } & & & $-0.1284^{*}$ & -0.1146 & -0.0532 & $-0.2888 * *$ & -0.0704 \\
\hline & & & -1.92 & -1.65 & -0.88 & -2.63 & -0.73 \\
\hline \multirow[t]{2}{*}{ Cash Flow } & & & -0.0639 & -0.1325 & $-0.2036^{* * *}$ & $0.2113^{* *}$ & -0.0840 \\
\hline & & & -0.74 & -1.43 & -2.98 & 2.07 & -0.76 \\
\hline \multirow[t]{2}{*}{ Intercept } & $0.1274 * * *$ & $0.4377 * * *$ & $0.4730^{* * *}$ & $0.4147 * * *$ & $0.5565^{* * *}$ & $0.3540^{* *}$ & $0.2740 * *$ \\
\hline & 3.64 & 5.96 & 5.96 & 5.24 & 6.14 & 2.49 & 2.22 \\
\hline Fixed Effects & Firm & Firm & Firm & Firm & Firm & Firm & Firm \\
\hline Clusters & Industry & Industry & Industry & Industry & Industry & Industry & Industry \\
\hline Observations & 70,929 & 70,462 & 65,187 & 58,563 & 60,147 & 34,585 & 30,602 \\
\hline
\end{tabular}




\section{Appendix A}

This appendix details the construction of all variables used throughout the paper. Compustat abbreviations have been recorded parenthetically as appropriate.

\begin{tabular}{|c|c|}
\hline Illiquidity & $\begin{array}{l}\text { Illiquidity is defined by equation (1) and is calculated as cash (CHE) } \\
\text { times } 1 \text { plus receivables (RECT) times two plus inventory (INVT) times } \\
\text { three plus other current assets (ACO) times four plus property, plant, and } \\
\text { equipment (PPENT) times five plus other investments (IVAEQ) times } \\
\text { six plus investments in equity (IVAO) times seven plus intangibles } \\
\text { (INTAN) times eight plus other assets (AO) times nine scaled by } 45 \\
\text { times lagged total assets. }\end{array}$ \\
\hline $\begin{array}{l}\text { GKP Weighted } \\
\text { Asset Liquidity } 1\end{array}$ & $\begin{array}{l}\text { GKP Weighted Asset Liquidity } 1 \text { is cash }(\mathrm{CHE}) \text { scaled by lagged total } \\
\text { assets (AT). }\end{array}$ \\
\hline $\begin{array}{l}\text { GKP Weighted } \\
\text { Asset Liquidity } 2\end{array}$ & $\begin{array}{l}\text { GKP Weighted Asset Liquidity } 2 \text { is cash (CHE) scaled by lagged total } \\
\text { assets (AT) plus one half times total current assets (ACT) less cash } \\
\text { (CHE) scaled by lagged total assets (AT). }\end{array}$ \\
\hline $\begin{array}{l}\text { GKP Weighted } \\
\text { Asset Liquidity } 3\end{array}$ & $\begin{array}{l}\text { GKP Weighted Asset Liquidity } 3 \text { is cash (CHE) scaled by lagged total } \\
\text { assets (AT) plus three quarters times total current assets (ACT) less cash } \\
\text { (CHE) scaled by lagged total assets (AT) plus one half times total assets } \\
\text { less total current assets less intangible assets scaled by lagged total assets } \\
\text { (AT). }\end{array}$ \\
\hline Cash Flow & $\begin{array}{l}\text { Cash flow is defined following Bates, Kahle, and Stulz (2009) as } \\
\text { earnings before interest and tax (EBIT) plus depreciation (DP) less } \\
\text { interest expense (XINT) less common dividends (DVC) scaled by total } \\
\text { assets (AT). }\end{array}$ \\
\hline $\begin{array}{l}\text { Historic Cash Flow } \\
\text { Volatility }\end{array}$ & $\begin{array}{l}\text { Historic cash flow volatility is calculated as the standard deviation of } \\
\text { cash flow over the years } t-10 \text { to } t-1 \text {. We require a minimum of } 3 \text { cash } \\
\text { flow observations to be included in the sample. This measure is } \\
\text { consistent with Bates, Kahle, and Stulz (2009). }\end{array}$ \\
\hline $\begin{array}{l}\text { Industry Cash } \\
\text { Flow Volatility }\end{array}$ & $\begin{array}{l}\text { Industry cash flow volatility is the average cash flow volatility by } \\
\text { industry and year. We define industry by two-digit SIC code. This } \\
\text { measure is consistent with Bates, Kahle, and Stulz (2009). }\end{array}$ \\
\hline $\begin{array}{l}\text { Future Cash Flow } \\
\text { Volatility }\end{array}$ & $\begin{array}{l}\text { Future cash flow volatility is calculated as the standard deviation of cash } \\
\text { flow over the years } t+1 \text { to } t+10 \text {. We require a minimum of } 3 \text { cash flow } \\
\text { observations to be included in the sample. }\end{array}$ \\
\hline
\end{tabular}




\begin{tabular}{|c|c|}
\hline Market to Book & $\begin{array}{l}\text { Market to Book, for the cashflow volatility regressions, is the market } \\
\text { capitalization scaled by the book equity of the firm. We define this as } \\
\text { common shares outstanding (CSHO) multiplied by the price at the end } \\
\text { of the fiscal year (PRCC_F). For the Fama-MacBeth regressions, market } \\
\text { capitalization is defined as the common shares outstanding at the end of } \\
\text { June of year } t \text { multiplied by the price at the end of June of year } t \text {. }\end{array}$ \\
\hline Real Size & Real Size is the natural log of total assets (AT). \\
\hline $\begin{array}{l}\text { Capital } \\
\text { Expenditures }\end{array}$ & $\begin{array}{l}\text { Capital expenditures is the total capital investments (CAPX) made in the } \\
\text { year scaled by lagged total assets (AT). }\end{array}$ \\
\hline Cash Ratio & $\begin{array}{l}\text { Cash Ratio is defined as the cash and cash equivalents (CHE) divided by } \\
\text { total assets (AT). }\end{array}$ \\
\hline $\begin{array}{l}\text { Change in Cash } \\
\text { Ratio }\end{array}$ & $\begin{array}{l}\text { Change in Cash Ratio is defined as the difference between the cash ratio } \\
\text { in the current year and the cash ratio in the prior year. }\end{array}$ \\
\hline R\&D to Sales & $\begin{array}{l}\text { R\&D to Sales is defined as the research and development (XRD) cost } \\
\text { scaled by total sales (SALE). We replace missing values of research and } \\
\text { development (XRD) with zero. }\end{array}$ \\
\hline $\begin{array}{l}\text { Net Working } \\
\text { Capital }\end{array}$ & $\begin{array}{l}\text { Net Working Capital is defined as the total current assets (ACT) less } \\
\text { total current liabilities (LCT) scaled by total assets (AT). }\end{array}$ \\
\hline Leverage & $\begin{array}{l}\text { Leverage is defined as the long-term debt (DLTT) plus total current } \\
\text { liabilities (LCT) scaled by total assets (AT). }\end{array}$ \\
\hline Size & $\begin{array}{l}\text { Size is defined as the market capitalization of the firm at portfolio } \\
\text { formation, which is the price at the end of June of year } t \text { multiplied by } \\
\text { the shares outstanding at the end of June of year } t \text {. }\end{array}$ \\
\hline Return on Assets & $\begin{array}{l}\text { Return on Assets is earnings before interest and taxes (EBIT) scaled by } \\
\text { lagged total assets (AT). }\end{array}$ \\
\hline Momentum & ound returns from month $t-12$ to month $t-1$. \\
\hline
\end{tabular}

